\title{
Aplikasi Peramalan Kebutuhan Beban Listrik Menggunakan Metode Adaptive Neuro Fuzzy Inference System (ANFIS)
}

\author{
Erwan Ahmad Ardiansyah ${ }^{1}$, Rina Mardiati ${ }^{2}$, Afaf Fadhil ${ }^{3}$ \\ ${ }^{1,2}$ Jurusan Teknik Elektro, Fakultas Sains dan Teknologi, UIN Sunan Gunung Djati Bandung \\ Jl. A.H. Nasution No. 105 Bandung \\ ${ }^{3}$ Teknik Otomasi Manufaktur dan Mekatronika, Politeknik Manufaktur Negeri Bandung \\ e-mail: ${ }^{1}$ ardiansyaherwan40@gmail.com, ${ }^{2}$ r_mardiati@uinsgd.ac.id, ${ }^{3}$ afaffadhil@gmail.com
}

\begin{abstract}
Abstrak - Prakiraan atau peramalan beban listrik dibutuhkan dalam menentukan jumlah listrik yang dihasilkan. Ini menentukan agar tidak terjadi beban berlebih yang menyebabkan pemborosan atau kekurangan beban listrik yang mengakibatkan krisis listrik di konsumen. Oleh karena itu di butuhkan prakiraan atau peramalan yang tepat untuk menghasilkan energi listrik. Teknologi softcomputing dapat digunakan sebagai metode alternatif untuk prediksi beban litrik jangka pendek salah satunya dengan metode Adaptive Neuro Fuzzy Inference System pada penelitian tugas akhir ini. Data yang di dapat untuk mendukung penelitian ini adalah data dari APD PLN JAWA BARAT yang berisikan laporan data beban puncak bulanan penyulang area gardu induk majalaya dari januari 2011 sampai desember 2014 sebagai data acuan dan data aktual januari-desember 2015. Data kemudian dilatih menggunakan metode ANFIS pada software MATLAB versi b2010. Dari data hasil pelatihan data ANFIS kemudian dilakukan perbandingan dengan data aktual dan data metode regresi meliputi perbandingan anfis-aktual, regresiaktual dan perbandingan anfis-regresi-aktual. Dari perbandingan disimpulkan bahwa data metode anfis lebih mendekati data aktual dengan rata-rata 1,4\%, menunjukan prediksi ANFIS dapat menjadi referensi untuk peramalan beban listrik dimasa depan.
\end{abstract}

Kata Kunci: Peramalan Beban Listrik, ANFIS, Logika Fuzzy.

\section{Pendahuluan}

Industri yang berada di kawasan bandung timur kian meningkat seiring dengan pertumbuhan ekonomi di kawasan tersebut selain itu banyak juga industri rumahan di daerah majalaya, cicalengka dan sekitarnya yang meningkat seperti industri rumah konveksi kerudung dan pakaian lainnya. Hal ini menjadikan kawasan tersebut menjadi bahan pertimbangan bagi PLN sebagai perusahaan penyedia layanan listrik untuk meningkatkan kualitasnya dan menyediakan listrik untuk kemajuan perekonomian di kawasan tersebut, oleh karena itu Peramalan kebutuhan beban listrik adalah salah satu aspek penting dalam perencanaan kebutuhan listrik. Kesalahan dalam melakukan peramalan kebutuhan listrik akan menyebabkan kekeliruan dalam perencanaan, rencana yang dibuat dibawah kebutuhan menyebabkan adanya konsumen yang tidak terlayani sehingga terjadi pemadaman listrik secara bergilir, rencana yang dibuat dapat pula melebihi kebutuhan sehingga terjadi infrastruktur kelistrikan yang tidak berfungsi optimal, ini menyebabkan kerugian secara finansial yang harus di tanggung akibat dari biaya infrastruktur kelistrikan yang cukup mahal.

Dalam meramalkan kebutuhan tenaga listrik tidak hanya didasarkian realisasi kebutuhan tenaga listrik tahun-tahun sebelumnya saja, melainkan dipengaaruhi juga oleh faktor-faktor lain. Dalam suatu daerah, misalkan jumlah penduduk dan pertumbuhan perekonomian daerah, sehingga peramalan yang bersifat kausalitas diperlukan untuk menentukan pola kecenderungan kebutuhan tenaga listrik dalam suatu deret waktu [1].

Industri yang berada di kawasan bandung timur kian meningkat seiring dengan pertumbuhan ekonomi di kawasan tersebut selain itu banyak juga industri rumahan di daerah majalaya, TELKA, Vol.3, No.1, Mei 2017, pp. 36 48 
cicalengka dan sekitarnya yang meningkat seperti industri rumah konveksi kerudung dan pakaian lainnya. Hal ini menjadikan kawasan tersebut menjadi bahan pertimbangan bagi PLN sebagai perusahaan penyedia layanan listrik untuk meningkatkan kualitasnya dan menyediakan listrik untuk kemajuan perekonomian di kawasan tersebut, oleh karena itu Peramalan kebutuhan beban listrik adalah salah satu aspek penting dalam perencanaan kebutuhan listrik. Kesalahan dalam melakukan peramalan kebutuhan listrik akan menyebabkan kekeliruan dalam perencanaan, rencana yang dibuat dibawah kebutuhan menyebabkan adanya konsumen yang tidak terlayani sehingga terjadi pemadaman listrik secara bergilir, rencana yang dibuat dapat pula melebihi kebutuhan sehingga terjadi infrastruktur kelistrikan yang tidak berfungsi optimal, ini menyebabkan kerugian secara finansial yang harus di tanggung akibat dari biaya infrastruktur kelistrikan yang cukup mahal.

Dalam meramalkan kebutuhan tenaga listrik tidak hanya didasarkian realisasi kebutuhan tenaga listrik tahun-tahun sebelumnya saja, melainkan dipengaaruhi juga oleh faktor-faktor lain. Dalam suatu daerah, misalkan jumlah penduduk dan pertumbuhan perekonomian daerah, sehingga peramalan yang bersifat kausalitas diperlukan untuk menentukan pola kecenderungan kebutuhan tenaga listrik dalam suatu deret waktu[1].

Dalam metode adaptive neuro fuzzy inference system, Adaptive Neuro Fuzzy Inference System (ANFIS) merupakan suatu teknik optimasi yang menggabungkan konsep neural network dengan fuzzy logic. Neural network mengenal pola-pola dan menyesuaikan pola terhadap perubahan lingkungan, sedangkan fuzzy logic menggabungkan pengetahuan manusia dan mencari kesimpulan untuk membuat suatu keputusan. Fuzzy Inference System merupakan proses perhitungannya berdasarkan himpunan fuzzy-logic. Aturan "jika-maka" dan operator logika fuzzy. FIS memetakan input yang diketahui ke output dengan menggunakan logika fuzzy[1].

\section{Dasar Teori}

\subsection{Pengertian Peramalan}

Pada dasarnya peramalan merupakan suatu dugaan atau perkiraan atas terjadinya kejadian di waktu mendatang. Ramalan bisa bersifat kualitaif maupun kuantitaif. Ramalan kualitatif tidak berbentuk angka, misalkan besok akan turun hujan, tahun depan akan terjadi perang, hasil penjualan tahun depan akan meningkat dan sebagainya. Sedangkan ramalan kuantitatif dinyatakan dalam bentuk angka atau bilangan. Ramalan kuantitatif sendiri digabi dua jenis yaitu: Ramalan Tunggal dan Ramalan Selang [2].

\subsubsection{Prinsip Peramalan}

Peramalan memiliki empat karakteristik atau prinsip. Dengan memahami prinsip-prinsip membantu agar mendapatkan peramalan yang lebih efektif [2].

1. Peramalan biasanya salah. Dalam kegiatan peramalan kesalahan adalah hal yang wajar karena masa depan yang tidak diketahui oleh siapapun.

2. Setiap peramalan seharusnya menyertakan estimasi kesalahan (error). Perbedaan antara nilai yang diprediksikan dengan nilai aktualnya akan menghasilkan besar kesalahan sehingga setiap peramalan seharusnya juga menyertakan estimasi kesalahan yang daat diukur sebagai tingkat kepercayaan, dapat berupa persentase (plus atau minus) dan maksimum (batas atas).

3. Peramalan akan lebih akurat untuk kelompok atau group. Perilaku dari individual dalam sebuah grup memiliki sifat yang lebih acak bahkan ketika sebuah grup memiliki sifat yang lebih acak bahkan ketika grup tersebut berada dalam keadaan stabil. Sebagai contoh, meramalkan secara akurat seorang murid dalam suatu kelas lebih sulit daripada meramalkan untuk rata-rata keseluruhan kelas. Dengan kata lain, peramalan lebih akurat untuk dilakukan pada kelompok atau grup dibandingkan individual.

4. Peramalan lebih akurat untuk jangka waktu yang lebih dekat. Kebanyakan orang lebih yakin untuk meramalkan apa yang akan mereka lakukan minggu depan dibanding meramalkan apa 
yang akan mereka lakukan tahun depan. Karena masa depan yang lebih jauh memiliki nilai ketidak pastian yang tinggi dibandingkan masa depan dalam jangka waktu pendek.

\subsubsection{Metode Peramalan}

Ada beberapa metode yang biasa digunakan untuk melakukan peramalan tergantung pada jenis peramalan yang akan dilakukan[3].

1. Metode peramalan dan jangka panjang. Faktor waktu yang mempengaruhi tipe ini adalah tahunan hingga bulanan. Pada umumnya metode yang digunakan: End Use Model (model penggunaan terakhir), Econometric Models (Model Ekonometrik), Statistical Model Based Learning (Model Statistik Berdasarkan Pembelajaran)

2. Metode peramalan jangka pendek. Sejumlah besar variasi teknik statistik dan Artificial Intelegence telah dikembangkan sebagai metode peramalan jangka pendek (Similar Day Approach, Metode Regresi, Time Series, Neural Network (jaringan syaraf), Logika Fuzzy, Support Vector Machines (SVM).

\subsubsection{Tahapan Peramalan}

Metode peramalan diperlukan beberapa tahap yang harus dilalui diantaranya:

1. Menentukan jenis data yang digunakan dan melakukan analisis pola data dan karakteristik yang dimiliki.

2. Memilih metode peramalan yang digunakan. Ada banyak jenis metode peramalan yang dapat digunakan, oleh karena itu penggunaan metode harus disesuaikan dengan jenis data untuk pendapatan persentase error yang sekecil-kecilnya.

3. Menentukan parameter-parameter yang dapat membantu meningkatkan akurasi dari metode peramalan yang telah ditentukan agar persentase error dapat diperkecil.

4. Mengaplikasikan data-data acuan ke dalam metode yang telah ditentukan dan hasilnya akan menghasilkan nilai perkiraan beserta persentase error sebagai perbandingan antara nilai perkiraan dengan nilai aktualnya.

\subsection{Metode Adaptive Neuro-Fuzzy Inference System (ANFIS)}

Adaptive Neuro-Fuzzy Inference System (ANFIS) pertama kali diperkenalkan oleh lotfi A. Zadeh pada tahun 1965, dengan melihat kenyataan bahwa manusia dapat membuat keputusan lebih baik berdasarkan informasi yang bukan numerik dan kurang pasti. Dalam perkembangan berikutnya, diperkenalkan konsep variabel linguistik. Variabel linguistik adalah suatu variabel yang nilainya merupakan kata atau kalimat dan bukan bilangan. Pada implementasi berikutnya dengan aturan IF-THEN, sehingga konsep ini merupakan awal dari teori fuzzy [4].

Adaptive Neuro Fuzzy Inference System (ANFIS) merupakan suatu teknik optimasi yang menggabungkan konsep neural network dengan fuzzy logic. Neural network mengenal pola-pola dan menyesuaikan pola terhadap perubahan lingkungan, sedangkan fuzzy logic menggabungkan pengetahuan manusia dan mencari kesimpulan untuk membuat suatu keputusan. Fuzzy Inference System merupakan proses perhitungannya berdasarkan himpunan fuzzy-logic. Aturan "jika-maka" dan operator logika Fuzzy. FIS memetakan input yang diketahui ke output dengan menggunakan logika fuzzy. Adaptive Neuro Fuzzy Inference System merupakan suatu teknik optimasi yang menggabungkan neural network dan fuzzy logic. Neural Network mengenal pola, sedangkan Fuzzy Logic menggabungkan pengetahuan manusia dan menarik kesimpulan untuk membuat keputusan. ANFIS terbukti dapat memprediksi time-series yang bersifat Chaotic[5]. Setelah Sugeno memperkenalkan model Fuzzy dengan himpunan Fuzzy dan consedent-nya merupakan himpunan crisp maka terdapat isilah baru yang disebut fuzzy adaptive. Salah satu model fuzzy adaptive adalah ANFIS (adaptive neuro fuzzy inference system) yang dikemukakan oleh Roger $\operatorname{Jan}[5]$.

ANFIS (Adaptive Neuro Fuzzy Inference System) merupakan salah satu sistem dalam kelompok hybrid dalam softcomputing. Sistem hybrid merupakan perpaduan atau gabungan dari setidaknya dua metode softcomputing dengan tujuan untuk memperoleh algoritma yang lebih sempurna. Sistem neuro fuzzy berdasar pada sistem inference fuzzy yang dilatih menggunakan 
algoritma pembelajaran yang diturunkan dari sistem neural network. Dengan demikian, sistem neuro-fuzzy memiliki semua kelebihan yang dimiliki oleh sistem inference fuzzy dan sistem neural networks[5].

Adaptive Neuro Fuzzy Inference System (ANFIS) atau neuro fuzzy merupakan hasil perpaduan dari jaringan syaraf tiruan dan logika fuzzy. Untuk sistem berbasis aturan linguistik, teknik jaringan syaraf tiruan akan memberikan kemampuan pembelajaran dan adaptasi untuk mengekstraksi parameter-parameter (premis dan konsekuen) aturan fuzzy dari sekumpulan data numerik. Secara khusus, jaringan neuro fuzzy menghilangkan kekurangan dalam desain sistem fuzzy konvensional dimana perancang harus men-tuning (menala) dengan trial-error fungsi keanggotaan dari himpunan fuzzy yang didefinisikan pada masukan dan keluaran dan semesta pembicaraan. ANFIS adalah sistem inference fuzzy yang di implementasikan dalam jaringan adaptive. Pada ANFIS, parameter adalah fungsi keanggotaan premis dan konsekuensi. Pembelajaran anfis adalah pengubah parameter fungsi keanggotaan masukan dan keluaran. Pembelajaran anfis dapat menggunakan algoritma perambatan balik atau algoritma hybrid. Algoritma hybrid adalah gabungan antara algoritma perambat balik dengan metode kuadrat terkecil (least square estimate). Metode kuadrat terkecil digunakan untuk menentukan parameter konsekuensi, sedangkan perambatan balik digunakan untuk memperbaharui bobot premis[6].

\subsubsection{Proses Belajar ANFIS (Algoritma Belajar Hibrida)}

ANFIS dalam kerjanya menggunakan algoritma belajar hybrid, yaitu menggabungkan metode least square estimator (LSE) dan error backpropagation (EBP). Dalam struktur ANFIS metode EBP dilakukan di lapisan ke-1, sedangkan metode LSE dilakukan di lapisan ke 4[7].

Pada lapisan pertama parameternya merupakan parameter dari fungsi keanggotaan himpunan fuzzy sifatnya nonlinier terhadap keluaran sistem. Proses belajar pada parameter ini menggunakan EBP untuk memperbaharui nilai parameternya. Sedangkan pada lapisan ke-4, parameter merupakan parameter linier terhadap keluaran sistem, yang menyusun basis kaidah fuzzy. Proses belajar untuk memperbaharui parameter. Lapisan ini menggunakan metode LSE. Proses belajar ANFIS dapat dilihat pada Tabel 1.

Tabel 1. Proses Belajar ANFIS [7]

\begin{tabular}{|l|l|l|}
\hline & Arah Maju & Arah Mundur \\
\hline Parameter Premis & Tetap & EBP \\
\hline Parameter Konsekuen & $\begin{array}{l}\text { Least-squeres } \\
\text { Estimator }\end{array}$ & Tetap \\
\hline Sinyal & keluaran simpul & Sinyal Kesalahan \\
\hline
\end{tabular}

Misalkan terdapat 2 input $\mathrm{x}$ dan y dengan masing-masing input memiliki 2 buah fungsi keanggotaan. Output jaringan yang dihasilkan yaitu $\mathrm{f}$ dengan 2 buah fungsi keanggotaan. Jika dalam suatu sistem hanya membutuhkan 2 buah aturan sebagai berikut:

$$
\begin{aligned}
& \text { If } x \text { is } A_{1} \text { and } y \text { is } B_{1} \text { then } f_{1}=p_{11} x_{1}+q_{12} x_{2}+r_{10} \\
& \text { If } x \text { is } A_{2} \text { and } y \text { is } B_{2} \text { then } f_{2}=p_{21} x_{1}+q_{22} x_{2}+r_{20}
\end{aligned}
$$

Maka dapat dihitung nilai rata-rata terbobot sebagai keluaran jaringan (f) dengan nilai firing strength untuk kedua aturan adalah $\mathrm{w}_{1}$ dan $\mathrm{w}_{2}$ :

$$
f=\frac{-w_{1} f_{1}+w_{2 f_{2}}}{w_{1}+w_{2}}
$$

ANFIS dibentuk dengan arsitektur jaringan seperti neural network yang memiliki beberapa lapisan terdiri dari lapisan input, lapisan tersembunyi, serta lapisan output. Pada setiap lapisan terdapat proses perhitungan yang pada akhirnya akan menghasilkan output jaringan ANFIS[10]. 


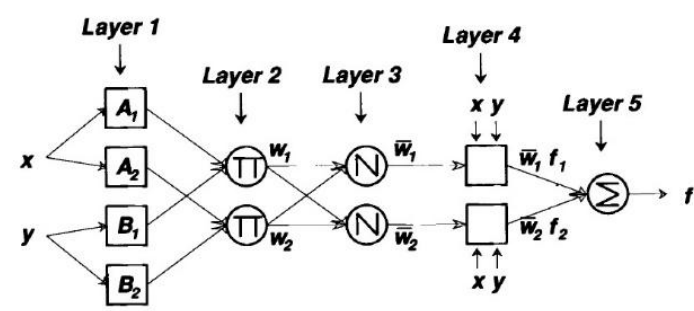

Gambar 1. Arsitektur Jaringan ANFIS [10]

\subsubsection{Membership Function (MF)}

Membership Function (MF) adalah kurva yang memetakan setiap titik pada inputan (universe of discourse) ke sebuah nilai keanggotaan (atau derajat keanggotaan) yang memiliki nilai antara 0 dan 1 yang didefinisikan secara matematis oleh persamaan:

$$
\mu_{\mathrm{A}}(x): \mathrm{X} \rightarrow[0,1]
$$

Setiap elemen $x$ dipetakan pada sebuah nilai keanggotaan oleh MF. Nilai ini merupakan derajat keanggotaan dari $x$ pada himpunan fuzzy.

$$
\mu_{\mathrm{A}}(\mathrm{x}): \text { Degree }(\mathrm{x} \in \mathrm{A})
$$

Dimana nilai keangotaan dari $x$ dibatasi oleh: $0 \leq \mu A(x) \leq 1$

Sebagai contoh pemetaan elemen dari $x$ (dalam hal ini adalah ketinggian seseorang) oleh MF ke nilai keanggotaannya, ditunjukkan dalam Gambar 2.

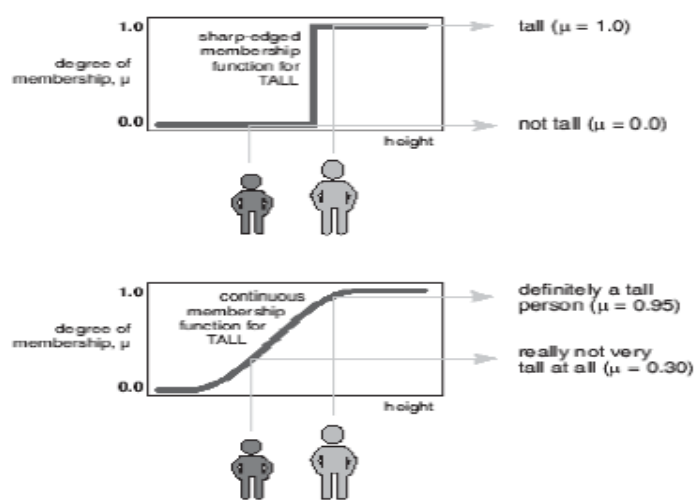

Gambar 2. Pemetaan ketinggian oleh MF [7]

Nilai keanggotaan hasil pemetaan elemen $x$ oleh suatu fungsi keanggotaan dapat memiliki nilai yang berbeda-beda tergantung pada jenis dari fungsi keanggotaan. Fungsi keanggotaan yang umum digunakan adalah: fungsi segitiga, fungsi trapesium, fungsi gaussian, fungsi bell dan fungsi sigmoid.

\section{Perancangan Sistem}

Data beban puncak pada penyulang $20 \mathrm{kV}$ di dapat dari PT PLN APD Jawa Barat sebagai penyedia layanan distribusi listrik negara kemudian data tersebut diolah yang sebelumnya berbentuk arus (Ampere) lalu diubah menjadi daya (watt) beban listrik yang di inginkan. Terdapat 48 data beban sebagai data input untuk mendapatkan data 12 output hal ini awal dari pembentukan FIS (Fuzzy Inference System). Setelah data di olah lalu kemudian data di latih dan di testing. 
Langkah awal untuk mendapatkan 12 keluaran dari data acuan 48 masukan adalah dengan memasukan data acuan atau data history ke Fuzzy Inference System (FIS) yang nantinya menerapkan berapa aturan yang akan di bentuk, berapa parameter yang dikeluarkan dan tipe function yang akan dipakai dimana ketiga fungsi ini menentukan tingkat akurasi dari metode anfis untuk peramalan beban listrik. Setelah nilai keluaran keluar 12 output maka dilanjutkan dengan melatih dan mentesting data.

Tabel 1. Data Aktual

\begin{tabular}{|c|c|c|c|c|c|}
\hline \multicolumn{7}{|c|}{ Rata-Rata Beban Tertinggi 2011-2014 } \\
\\
\hline Bulan & 2011 & 2012 & 2013 & 2014 & 2015 \\
\hline Januari & 5.08 & 5.1 & 5.18 & 4.9 & \\
\hline Febuari & 5.1 & 5.02 & 5 & 4.48 & \\
\hline maret & 5.08 & 4.96 & 4.84 & 5.16 & \\
\hline April & 5.36 & 4.46 & 5.12 & 4.92 & \\
\hline Mei & 5.32 & 5.06 & 5.34 & 4.72 & \\
\hline Juni & 5.42 & 5 & 5.1 & 5.2 & \\
\hline Juli & 4.96 & 4.98 & 4.98 & 4.6 & \\
\hline Agustus & 4.86 & 4.42 & 4.54 & 4.54 & \\
\hline September & 4.94 & 5.14 & 5.56 & 4.7 & \\
\hline Oktober & 5.42 & 5.28 & 5.3 & 5.42 & \\
\hline November & 5.2 & 5.08 & 5.02 & 5.1 & \\
\hline Desember & 4.86 & 4.92 & 5.03 & 5.16 & \\
\hline
\end{tabular}

Berdasarkan Tabel 1 diatas, menunjukan data sebelumnya yang terdiri dari 12 bulan 4 tahun untuk kemudian memprediksi data 12-24 bulan kedepan atau satu dua tahun kedepan sesuai urutan tahun yang akan di prediksi. Selanjutnya akan diterangkan perancangan aplikasi peramalan beban listrik dari permodelan anfis. Data yang akan di analisis adalah data dari bulan januari 2011 - desember 2014 untuk mendapatkan prediksi beban listrik pada bulan januari 2015 - desember 2015 untuk tahun pertama prediksi, perancangan model anfis hanya memasukan empat inputan untuk menghasilkan satu output jadi untuk memprediksi tahun 2016 dibutuhkan empat input data yaitu data dari tahun 2012 sampai 2015 begitu untuk seterusnya.

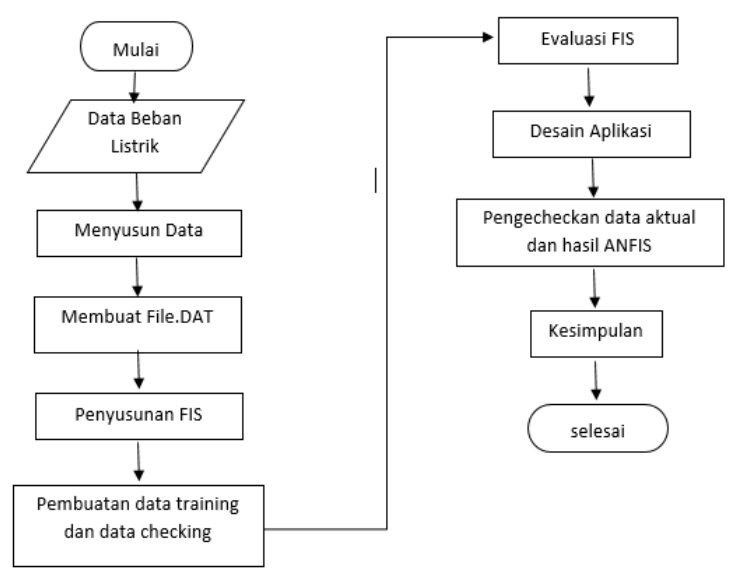

Gambar 3. Flowchart Tahapan Metode ANFIS 


\section{HASIL DAN ANALISIS SISTEM}

\subsection{Prediksi Beban Listrik Metode ANFIS}

Untuk memprediksi beban listrik penyulang area majalaya menggunakan metode ANFIS. Sebelumnya telah dirancang sedemikian rupa dan telah dibahas tahapan-tahapan mengenai perancangan sistem ANFIS. Rata-rata nilai peramalan atau prediksi ANFIS dengan data aktual dapat di lihat pada tabel berikut:

Tabel 2. Prediksi Beban Listrik Metode ANFIS

\begin{tabular}{|l|l|l|l|}
\hline Bulan & $\begin{array}{l}\text { Hasil } \\
\text { Ramalan } \\
(\mathbf{K w h}) \\
(\mathbf{F t})\end{array}$ & $\begin{array}{l}\text { Aktual } \\
(\mathbf{K w h}) \\
(\mathbf{X t )})\end{array}$ & $\begin{array}{l}\text { Error } \\
(\mathbf{K w h}) \\
(\mathbf{E t})\end{array}$ \\
\hline Januari & 5,42 & 5,38 & $-0,04$ \\
\hline Febuari & 5,07 & 5,16 & 0,09 \\
\hline Maret & 5,41 & 5,6 & 0,19 \\
\hline April & 5,43 & 4,98 & $-0,45$ \\
\hline Mei & 5,23 & 5,34 & 0,11 \\
\hline Juni & 5,76 & 5,5 & $-0,17$ \\
\hline Juli & 5,16 & 5,06 & $-0,09$ \\
\hline Agustus & 4,94 & 5 & 0,06 \\
\hline September & 5,4 & 4,98 & $-0,43$ \\
\hline Oktober & 5,96 & 5,48 & $-0,48$ \\
\hline November & 5,75 & 5,72 & $-0,03$ \\
\hline Desember & 5,7 & 5,58 & $-0,12$ \\
\hline
\end{tabular}

Untuk mengetahui selisih error dari perbandingan metode ANFIS dan Aktual dilakukan dengan menggunakan persamaan $\mathrm{Et}=\mathrm{Xt}-\mathrm{Ft}$. Dimana $: \mathrm{Et}=$ kesalahan atau Error, $\mathrm{Xt}=\mathrm{Nilai}$ Aktual, $\mathrm{Ft}=$ Nilai Hasil Peramalan.

Maka didapatkan hasil error pada bulan januari -0,04 Kwh yang menunjukan hasil ramalan melebihi nilai aktual, pada bulan Febuari didapat error $0,09 \mathrm{Kwh}$ yang menunjukan hasil ramalan kurang dari nilai aktual, bulan Maret error didapat 0,19 Kwh menunjukan hasil ramalan kurang dari nilai aktual, selanjutnya bulan April didapat error $-0,45 \mathrm{Kwh}$ yang artinya hasil ramalan melebihi nilai aktual, kemudian bulan Mei didapat error $0,11 \mathrm{Kwh}$ menunjukan hasil ramalan kurang dari nilai aktual, lanjut pada bulan Juni error -0,17 Kwh menunjukan hasil ramal melebihi nilai aktual, dilanjutkan pada bulan Juli nilai -0,09 Kwh menunjukan hasil ramal melebihi nilai aktual, bulan Agustus error 0,06 Kwh yang menunjukan hasil ramalan kurang dari nilai aktual, selanjutnya pada bulan September sampai Desember yaitu error -0,43 Kwh, -0,16 Kwh, $0,03 \mathrm{Kwh}$ dan $-0,12 \mathrm{Kwh}$ menunjukan hasil ramalan melebihi nilai aktual.

Ini menunjukan hasil peramalan menggunakan metode ANFIS rata-rata melebihi nilai aktual yaitu terjadi pada bulan Januari, April, Juni, Juli, September, Oktober, Nopember dan Desember. Sedangkan nilai yang kurang dari aktual pada bulan Febuari, Maret, Mei dan Agustrus. selanjutnya akan ditampilkan hasil peramalan ANFIS dan data aktual dalam bentuk grafik seperti gambar 4 berikut: 


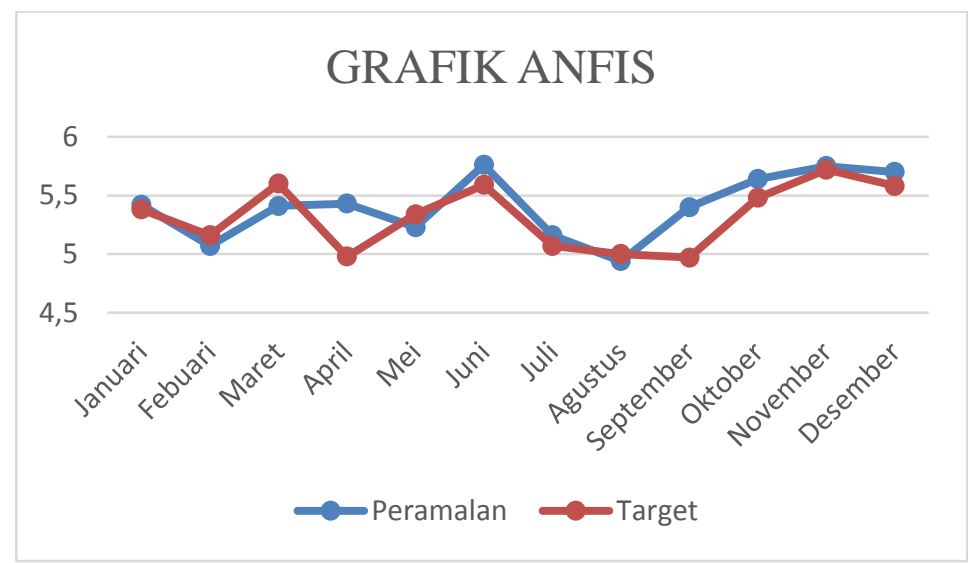

Gambar 4. Grafik Peramalan Beban Listrik Metode ANFIS

Hasil peramalan beban listrik bulanan yang yang telah dijelaskan sebelumnya dapat terlihat pada Gambar 4 menampilkan ramalan metode ANFIS rata-rata melebihi nilai aktual perbulannya. Ditunjukan garis berwarna biru hasil peramalan menggunakan metode ANFIS dan garis berwarna jingga adalah nilai aktual.

\subsection{Prediksi Beban Listrik Metode REGRESI}

Memperdeksi beban listrik penyulang menggunakan metode regresi linier memakai pola regresi linier satu variabel yang menentukan atau variabel bebas, secara matematis hubungan tersebut dapat dinotasikan sebagai $\mathrm{Y}=\mathrm{f}(\mathrm{X})$ dimana $\mathrm{Y}$ adalah variabel yang diramalkan (data masa lalu) dan $\mathrm{X}$ adalah variabel bebas dalam hal ini variabel bebasnya adalah waktu (periode). Berikut adalah tabel peramalan Regresi linier, data aktual dan nilai error yang didapat.

Tabel 3. Prediksi Beban Listrik Metode Regresi Linier (Sederhana)

\begin{tabular}{|l|c|c|c|}
\hline Bulan & $\begin{array}{c}\text { Hasil Ramalan (Kwh) } \\
(\mathbf{F t})\end{array}$ & $\begin{array}{c}\text { Aktual }(\text { Kwh) } \\
(\mathbf{X t )}\end{array}$ & $\begin{array}{c}\text { Error } \mathbf{( K w h )} \\
(\mathbf{E t})\end{array}$ \\
\hline Januari & 5,29 & 5,38 & $-0,09$ \\
\hline Febuari & 5,22 & 5,16 & $-0,06$ \\
\hline Maret & 5,15 & 5,6 & 0,45 \\
\hline April & 5,08 & 4,98 & $-0,1$ \\
\hline Mei & 5,01 & 5,34 & 0,33 \\
\hline Juni & 4,94 & 5,59 & 0,65 \\
\hline Juli & 4,87 & 5,07 & 0,2 \\
\hline Agustus & 4,81 & 5 & 0,19 \\
\hline September & 4,74 & 4,97 & 0,23 \\
\hline Oktober & 4,67 & 5,48 & 0,81 \\
\hline November & 4,6 & 5,72 & 1,12 \\
\hline Desember & 4,53 & 5,58 & 1,05 \\
\hline
\end{tabular}

*Ket: Nilai Kesalahan (error)

Jika Nilai Positif, artinya hasil ramalan lebih kecil dari nilai aktual Jika Nilai Negatif, artinya hasil ramalan lebih besar dari nilai aktual

Maka didapat error pada bulan Januari -0,09 Kwh menunjukan hasil ramalan melebihi nilai aktual, bulan Februari error $-0,06 \mathrm{Kwh}$ menunjukan hasil ramalan melebihi nilai aktual, selanjutnya bulan Maret error $0,45 \mathrm{Kwh}$ artinya hasil ramalan kurang dari nilai aktual, lanjut pada bulan April error -0,1 Kwh menunjukan hasil peramalan melebihi nilai aktual, berikutnya pada 
bulan Mei sampai dengan bulan Desember yaitu nilai error $0.33 \mathrm{Kwh}, 0.63 \mathrm{Kwh}, 0.2 \mathrm{Kwh}, 0.19$ $\mathrm{Kwh}, 0.23 \mathrm{Kwh}, 0.81 \mathrm{Kwh}, 1,12 \mathrm{Kwh}$ dan $1,05 \mathrm{Kwh}$ menunjukan hasil ramalan kurang dari nilai aktual.

Hasil peramalan menggunakan metode Regresi Linier dapat dilihat pada grafik yang telah dibuat pada gambar 5.2 di bawah sebagai berikut:

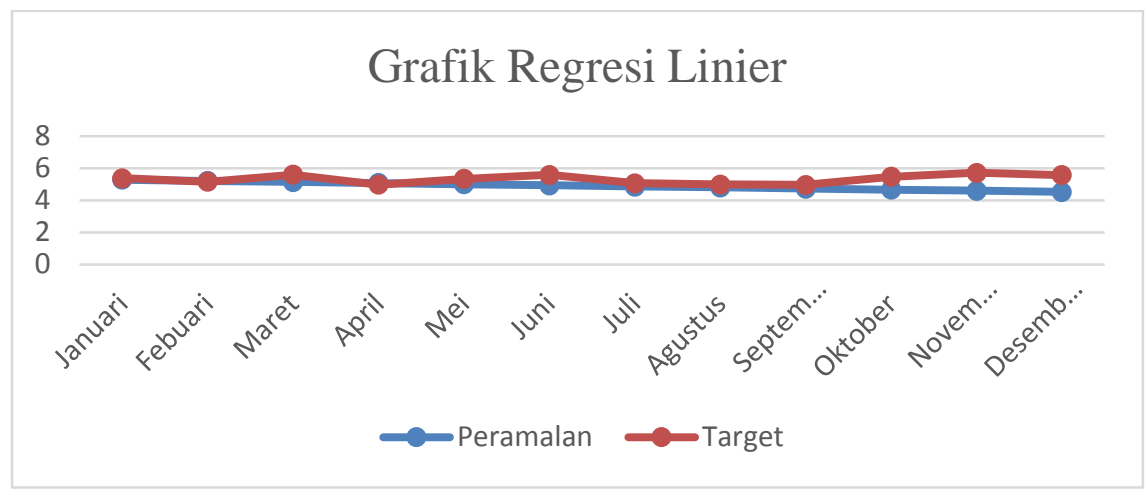

Gambar 5. Grafik Peramalan Beban Listrik Metode Regresi Linier

Hasil peramalan beban listrik penyulang bulanan dengan menggunakan metode regresi linier dapat dilihat pada grafik yang menampilan bulan Januari, Febuari nilai regresi linier dan nilai aktual mendekati dilanjut bulan April, Juni, Agustus dan September sama mendekati nilai aktual. Pada bulan Maret, Mei sampai dengan bulan Desember nilai hasil ramalan kurang dari nilai aktual.

Perbandingan Hasil Kesalahan dan Persentase kesalahan Metode ANFIS dan Regresi Linier

Perbandingan hasil kesalahan pada peramalan ANFIS dan Regresi Linier menjelaskan tingkat kesalahan yang mendekati nilai aktual dan persentase kesalahan pada metode ANFIS dan metode Regresi linier.

sebelum memperoleh nilai dari persentase kesalahan hasil peramalan metode ANFIS dan metode Regresi linier terlebih dahulu harus mengetahui nilai Mean Absolute Error (MAE) atau nilai kesalahan mutlak dengan persamaan: $M A E=|X t-F t|$ dimana $X t$ adalah nilai aktual dan Ft nilai hasil peramalan. Hal tersebut bertujuan untuk mengantisipasi kesalahan atau error yang bernilai negatif, sehingga dapat menentukan kesalahan dan mengetahui percentage error (persentase kesalahan). Untuk mendapat nilai persentase kesalahan dari peramalan metode ANFIS dan Regresi Linier menggunakan persamaan percentage error $P E=\frac{M A E}{X} \times 100 \%$. dimana $X$ adalah nilai aktual. Berikut tabel nilai MAE dan PE metode ANFIS, Regresi Linier.

Tabel 4. Perbandingan Persentase Kesalahan (Percentage Error)

\begin{tabular}{|c|c|c|c|c|}
\hline \multirow{2}{*}{ Bulan } & \multicolumn{2}{|l|}{ Mean Absolute Error (MAE) } & \multicolumn{2}{l|}{ Persentase error (PE) (\%) } \\
\cline { 2 - 5 } & ANFIS & Regresi Linier & ANFIS & Regresi Linier \\
\hline Januari & 0,04 & 0,09 & 0,74 & 1,67 \\
\hline Februari & 0,09 & 0,06 & 1,7 & 1,16 \\
\hline Maret & 0,19 & 0,45 & 3,39 & 8,03 \\
\hline April & 0,45 & 0,1 & 9,03 & 2 \\
\hline Mei & 0,11 & 0,33 & 2,05 & 6,17 \\
\hline Juni & 0,17 & 0,65 & 3,04 & 11,62 \\
\hline Juli & 0,09 & 0,2 & 1,77 & 3,94 \\
\hline Agustus & 0,06 & 0,19 & 1,2 & 3,8 \\
\hline
\end{tabular}




\begin{tabular}{|c|c|c|c|c|}
\hline September & 0,43 & 0,23 & 8,6 & 4,62 \\
\hline Oktober & 0,16 & 0,81 & 2,91 & 14,78 \\
\hline Nopember & 0,03 & 1,12 & 0,52 & 19.58 \\
\hline Desember & 0,12 & 1,05 & 2,15 & 18,81 \\
\hline Rata-rata & 0,16 & 0,44 & 3,09 & 6,96 \\
\hline
\end{tabular}

Hasil perbandingan antara metode ANFIS dan metode Regersi Linier dalam bentuk persen dapat dilihat pada gambar grafik 5.3 yang menunjukan hasil perbandingan yang sangat jauh dimana pada bulan Nopember mengalami perbedaan peramalan signifikan dimana hasil dari metode ANFIS 0.52 persen mendekati data aktual dan metode regresi linier sebesar 18,81 persen hasil yang cukup jauh dari data aktual kemudian untuk tingkat akurasi yang mendekati data aktual hasil dari metode ANFIS pada bulan Nopember yaitu sebesar 0.52 persen sedangkan yang di hasilkan dari metode Regresi linier pada bulan Februari yaitu sebesar 1.16 persen dari data aktual.

Persentase kesalahan yang didapat metode ANFIS dan metode Regresi Linier dengan rata-rata nilai persentase error yang di dapat dari hasil peramalan metode ANFIS sebesar 3,09\% sedangkan pada metode Regresi Linier sebesar 6,96\%.

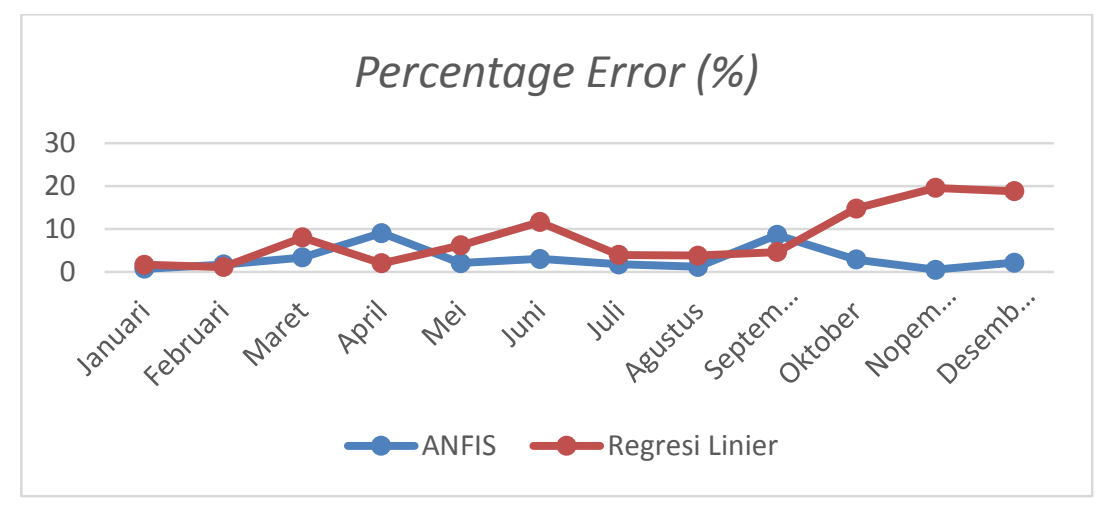

Gambar 6. Grafik Perbandingan (dalam bentuk persen)

Hasil persentase error pada peramalan beban listrik penyulang metode ANFIS dan metode Regresi Linier terlihat pada Gambar 6 yang menampilkan persentase pada bulan Januari dan Febuari sama-sama mendekati nilai aktual dan pada bulan-bulan selanjutnya terjadi persentase error yang berbeda jauh antara metode ANFIS dan Regresi Linier yaitu pada bulan Oktober, Nopember dan Desember.

\section{Perbandingan Peramalan Beban Listrik ANFIS, Regresi Linier dan AKTUAL}

Hasil dari nilai yang telah keluar dari peramalan beban listrik penyulang menggunakan metode ANFIS dan Regresi Linier kemudian telah didapat pula nilai kesalahan atau tingkat error pada metode ANFIS dan Regresi Linier juga telah dijelaskan sebelunya mengenai hasil nilai peramalan ANFIS dan Regresi Linier yang mendekati nilai aktual dilihat dari tingkat error dan juga telah dijelaskan pula mengenai tingkat persentase error pada metode ANFIS dan Regresi Linier juga penjelasan hasil peramalan yang mengalami nilai yang lebih banyak kurang dari nilai aktual. Berikut Tabel 5 perbandingan hasil peramalan Metode ANFIS dan Regresi linier dengan Aktual.

Tabel 5. Perbandingan Peramalan Beban Listrik

\begin{tabular}{|l|c|c|c|}
\hline \multirow{2}{*}{ BULAN } & \multicolumn{3}{|l|}{ PERAMALAN (Kwh) } \\
\cline { 2 - 4 } & ANFIS & Regresi Linier & AKTUAL \\
\hline Januari & 5,42 & 5,29 & 5,38 \\
\hline Februari & 5,07 & 5,22 & 5,16 \\
\hline
\end{tabular}




\begin{tabular}{|l|c|c|c|}
\hline \multirow{2}{*}{ BULAN } & \multicolumn{3}{|l|}{ PERAMALAN (Kwh) } \\
\cline { 2 - 4 } & ANFIS & Regresi Linier & AKTUAL \\
\hline Maret & 5,41 & 5,15 & 5,6 \\
\hline April & 5,43 & 5,08 & 4,98 \\
\hline Mei & 5,23 & 5,01 & 5,34 \\
\hline Juni & 5,76 & 4,94 & 5,59 \\
\hline Juli & 5,16 & 4,87 & 5,07 \\
\hline Agustus & 4,94 & 4,81 & 5 \\
\hline September & 5,4 & 4,74 & 4,97 \\
\hline Oktober & 5,64 & 4,67 & 5,48 \\
\hline Nopember & 5,75 & 4,6 & 5,72 \\
\hline Desember & 5,7 & 4,53 & 5,58 \\
\hline
\end{tabular}

Berdasarkan penjelasan yang telah dibahas sebelumnya perbandingan peramalan metode ANFIS dan metode Regresi Linier dengan nilai aktual maka didapat hasil error antara metode ANFIS dengan nilai aktual dan metode Regresi Linier dengan nilai aktual diantaranya empat periode metode ANFIS kurang dari nilai aktual yaitu pada bulan Febuari, Maret, Mei Dan Juni, dan delapan periode yang melebihi nilai aktual yaitu bulan Januari, April, Juli, September sampai Desember. Sedangkan pada peramalan menggunakan metode regresi linier terjadi dua periode yang melebihi nilai aktual yaitu periode bulan Febuari dan April selebihnya kurang dari nilai aktual.

Perbandingan antara metode ANFIS dan metode Regresi linier pada nilai kesalahan (error) yang lebih kecil artinya nilai peramalan mendekati nilai aktual. Pada hasil peramalan metode ANFIS dan Regresi Linier terdapat sembilan periode hasil peramalan metode ANFIS yang lebih mendekati dan ada tiga periode hasil peramalan metode Regresi Linier yang mendekati nilai aktual.

Persentase kesalahan yang didapat metode ANFIS dan metode Regresi Linier denang rata-rata nilai persentase error yang di dapat dari hasil peramalan metode ANFIS sebesar 3,09\% sedangkan pada metode Regresi Linier sebesar 6,96\%. Grafik Perbandingan peramalan beban listrik menggunakan metode ANFIS, Regresi Linier dan Aktual selama satu tahun di perlihatkan pada Gambar 7.

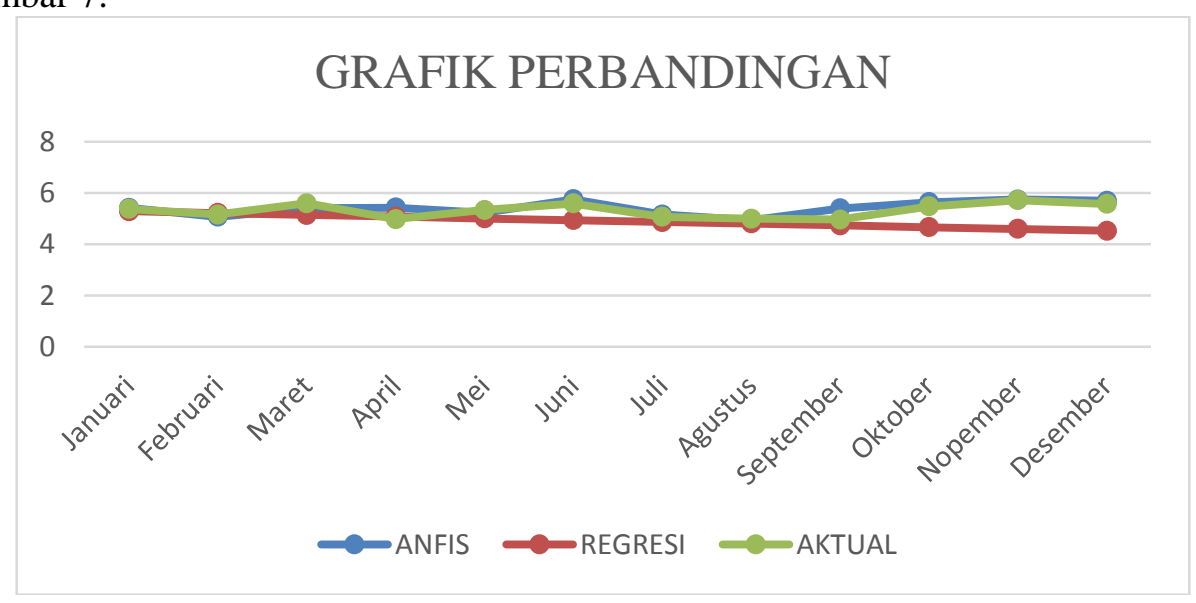

Gambar 7. Grafik Perbandingan Peramalan Beban Listrik

Pada Gambar 7 grafik perbandingan antara nilai hasil peramalan metode ANFIS dan Metode Regresi Linier dengan nilai aktual terlihat pada bulan Januari dan Febuari hasil peramalan Metode ANFIS dan Regresi Linier keduanya mendekati nilai aktual. Pada metode ANFIS garis berwarna biru mendekati terus mendekati nilai aktual, sedangkan metode Regresi Linier terlihat jauh pada bulan Juni, Oktober, Nopember dan Desember. 


\section{PENUTUP}

\subsection{Kesimpulan}

Berdasarkan hasil penelitian yang sudah dilakukan, maka hasil dari penelitian ini dapat disimpulkan sebagai berikut:

1. Aplikasi Peramalan beban listrik penyulang dengan menggunakan metode ANFIS telah berhasil dibuat dengan menggunakan data beban masa lalu yaitu dengan data beban 48 bulan data acuan (masa lalu) kemudian menghasilkan data beban 12 bulan mendatang. Selebihnya untuk data input 36 bulan disimpan di database dan 12 bulan sisanya di input secara manual guna memudahkan user ketika akan melakukan peramalan beban listrik penyulang pada tahuntahun mendatang.

2. Nilai rata-rata kesalahan dari kedua metode dalam waktu 1 tahun dengan rincian perbulan metode Regresi linier yaitu dengan rata-rata sebesar 6,96\% dari data aktual. Sedangkan nilai kesalahan dari ANFIS yaitu dengan rata-rata sebesar 3,09\% dari data aktual. maka dapat disimpulkan peramalan beban listrik menggunakan metode ANFIS lebih mendekati nilai aktual dibandingkan dengan metode peramalan beban listrik yang digunakan metode Regresi linier.

\subsection{Saran}

Berdasarkan hasil pengambilan kesimpulan yang diperoleh dari data hasil simulasi aplikasi, maka ada beberapa saran yang mudah-mudahan dapat bermanfaat bagi pihak manapun yang terkait dengan studi ini:

1. Bagi dunia praktis, dalam hal ini PLN, disarankan untuk mengkaji ulang mengenai Adaptive Neuro Fuzzy Inference System untuk peramalan beban listrik jangka menengah yang dijalankan dengan logika Fuzzy sebagai alternative metode peramalan beban listrik .

2. Bagi peneliti yang tertarik dengan peramalan beban listrik menggunakan logika fuzzy, masih terdapat banyak faktor yang belum dimasukan dalam tugas akhir ini, diantaranya faktor cuaca, faktor suhu dan faktor-faktor lainnya seperti perbedaan waktu liburan, hari raya dan hari kerja yang jika dimasukan maka hasil penelitian ini akan lebih akurat.

\section{DAFTAR PUSTAKA}

[1] Maulana rizki, 2012 "prediksi curah hujan dan debit menggunakan metode adaptive neurofuzzy inference system (ANFIS) studi kasus citarum hulu”. Tugas Akhir. Institut Teknologi Bandung. Bandung

[2] Maju binoto, 2012, "peramalan beban listrik jangkapendek menggunakan jaringan syaraf tiruan di kabupaten karanganyar-jawa tengah". Tugas Akhir. Universitas brawijaya. Malang

[3] Aulia Khair, 2011, "peramalan beban listrik jangka pendek menggunakan kombinasi metode autoregresive integrated moving average (ARIMA) dengan regresi linear antara suhu dan daya listrik". Tugas Akhir. Universitas Indonesia. Depok

[4] sarjon defit, 2013, "perkiraan beban listrik jangka pendek menggunakan metode adaptive neuro fuzzy inference system". Tugas Akhir. Universitas Putra Indonesia. padang

[5] supriyono, 2006, "aplikasi logika fuzzy pada optimasi daya listrik sebagai sistem pengambil keputusan”. Tugas Akhir. Sekolah tinggi teknologi nuklir-BATAN. Yogyakarta.

[6] Sayudha Lukita Wibisana, 2013, "Prakiraan beban listrik jangka pendek menggunakan adaptive neuro fuzzy inference system (ANFIS)". Tugas Akhir. Universitas Islam Negeri Sunan Gunung Djati. Bandung.

[7] Muhammad Alfarabi, 2014, "rancang bangun sistem pengenalan suara dengan metode adaptive neuro fuzzy interference system (ANFIS)". Tugas Akhir. Universitas Islam Negeri Sunan Gunung Djati. Bandung. 
[8] Dr.Ir Prabowo Pudjo Widodo, M.S, Rahmadya Trias Handayanto, ST., M.Kom., Herlawati,S.Si., MM, M,Kom. 2013, "Penerapan data mining dengan matlab". Buku. Rekayasa sains. Bandung.

[9] Sri Kusumadewi, Hari Purnomo, 2010, "Aplikasi Logika Fuzzy untuk pendukung keputusan”. Buku edisi 2. Graha Ilmu. Yogyakarta.

[10] Gafar Abdullah Ade, 2008, "short term load forcastting melalui pendekatan logika fuzzy", Universitas Pendidikan Indonesia. Bandung. 